\title{
Role of $5-\mathrm{HT}_{3}$ receptors in basal and $\mathrm{K}^{+}$-evoked dopamine release from rat olfactory tubercle and striatal slices
}

\author{
A. Zazpe, I. Artaiz \& J. 'Del Río
}

Department of Pharmacology, School of Medicine, University of Navarra, 31080-Pamplona, Spain

1 The present study was aimed at examining the role of $5-\mathrm{HT}_{3}$ receptors in basal and depolarizationevoked dopamine release from rat olfactory tubercle and striatal slices. $\left[{ }^{3} \mathrm{H}\right]$-dopamine $\left(\left[{ }^{3} \mathrm{H}\right]-\mathrm{DA}\right)$ release was measured in both brain regions and endogenous dopamine release from striatal slices was also studied.

2 The selective 5- $\mathrm{HT}_{3}$ receptor agonist 2-methyl-5-HT $(0.5-10 \mu \mathrm{M})$ produced a concentrationdependent increase in $\left[{ }^{3} \mathrm{H}\right]-\mathrm{DA}$ efflux evoked by $\mathrm{K}^{+}(20 \mathrm{mM})$ from slices of rat olfactory tubercle. 1-Phenylbiguanide (PBG) and 5-HT also increased $\mathrm{K}^{+}$-evoked $\left[{ }^{3} \mathrm{H}\right]$-DA efflux.

3 5-HT $(1-100 \mu \mathrm{M})$ increased in a concentration-dependent manner basal $\left[{ }^{3} \mathrm{H}\right]-\mathrm{DA}$ release from olfactory tubercle and striatal slices as well as endogenous DA release from striatal slices. The selective 5-HT $\mathrm{H}_{3}$ receptor agonists 2-methyl-5-HT and 1-phenylbiguanide were weaker releasing agents. In all cases, the release was $\mathrm{Ca}^{2+}$ independent and tetrodotoxin insensitive.

$45-\mathrm{HT}_{3}$ receptor antagonists such as ondansetron, granisetron and tropisetron $(0.2 \mu \mathrm{M})$ significantly blocked the enhanced $\mathrm{K}^{+}$-evoked $\left[{ }^{3} \mathrm{H}\right]$-DA efflux from rat olfactory tubercle slices induced by 2 -methyl5-HT. A ten fold higher concentration of the 5- $\mathrm{HT}_{2}$ receptor antagonist ketanserin was ineffective.

5 Much higher concentrations, up to $50 \mu \mathrm{M}$, of the same 5-HT $\mathrm{H}_{3}$ receptor antagonists did not block the increase in basal $\left[{ }^{3} \mathrm{H}\right]$-DA release from striatal or olfactory tubercle slices induced by 5 -HT or the release of endogenous DA induced by 5-HT from striatal slices.

6 The DA uptake blocker nomifensine $(10 \mu \mathrm{M})$ did not modify the enhancement in $\mathrm{K}^{+}$-evoked $\left[{ }^{3} \mathrm{H}\right]-\mathrm{DA}$ efflux from rat olfactory tubercle slices induced by 2 -methyl-5-HT. However, both nomifensine and cocaine significantly blocked the increase in basal dopamine release, either tritiated or endogenous, induced by $5-\mathrm{HT}$.

7 These results indicate that $5-\mathrm{HT}_{3}$ receptors only modulate DA release when the terminal fields of dopaminergic systems have been activated. In basal conditions, 5- $\mathrm{HT}_{3}$ receptor agonists enhance DA release through a carrier-mediated mechanism. This may be of therapeutic relevance for the possible use of $5-\mathrm{HT}_{3}$ receptor antagonists under conditions of abnormal activation of the dopaminergic system.

Keywords: Dopamine release; 5-hydroxytryptamine; 5- $\mathrm{HT}_{3}$ receptors; olfactory tubercle; striatum; 2-methyl-5-hydroxytryptamine; 1-phenylbiguanide; ondansetron; granisetron; tropisetron

\section{Introduction}

It has been suggested that antagonists at 5-hydroxytryptamine $_{3}\left(5-\mathrm{HT}_{3}\right)$ receptors may be of value in the treatment of withdrawal reactions to drugs of abuse such as cocaine, morphine or ethanol (see reviews in Palfreyman et al., 1993; Hagan et al., 1993) and also in the treatment of schizophrenia (Hagan et al., 1993). One of the mechanisms involved in these hypothetical therapeutic effects would be a blockade of the mesolimbic dopamine system activation induced by $5-\mathrm{HT}_{3}$ receptor stimulation (Costall et al., 1987; Hagan et al., 1987). It is known that agonists at this 5-HT receptor subtype are able to release dopamine from striatal and limbic regions both in vitro (Blandina et al., 1989; Schmidt \& Black, 1989; Yi et al., 1991; Benuck \& Reith, 1992; Jacocks \& Cox, 1992) and in vivo (Jiang et al., 1990; Chen et al., 1991). Some in vitro experiments suggest that dopamine release by $5-\mathrm{HT}_{3}$ agonists is a receptor-mediated effect (Blandina et al., 1989), while many other studies indicate that the release is carrier mediated (Schmidt \& Black, 1989; Yi et al., 1991; Benuck \& Reith, 1992; Jacocks \& Cox, 1992).

There is much behavioural, electrophysiological and neurochemical evidence suggesting that the 5-HT system may modulate the dopaminergic system, especially when the latter has been activated. In this regard, particular attention has been paid to $5-\mathrm{HT}_{3}$ receptors found in moderately high levels in terminal regions of the mesolimbic dopaminergic system,

\footnotetext{
' Author for correspondence.
}

such as the nucleus accumbens, olfactory tubercle and amygdala (Kilpatrick et al., 1988; Waeber et al., 1989; Barnes et al., 1990). Ondansetron, a typical 5- $\mathrm{HT}_{3}$ receptor antagonist, is able to block the behavioural effects of amphetamine, a dopamine-releasing drug, when amphetamine is injected into the nucleus accumbens but not when given systemically (Costall et al., 1987). Ondansetron also attenuates the increase in dopamine turnover induced by injection of the neurokinin agonist DiMe-C7 into the ventral tegmental area (Hagan et al., 1987). Chronic administration of another 5- $\mathrm{HT}_{3}$ antagonist, MDL-73147EF, decreases the number of spontaneously active dopaminergic neurones in the ventral tegmental area (A10) (Sorensen et al., 1989), which have been associated with the rewarding effect of drugs of abuse (Koob \& Bloom, 1988). Tropisetron reverses the increase in dopamine release resulting from stress (Imperato et al., 1990) or from the administration of morphine, nicotine and ethanol (Carboni $e t$ al., 1989).

The present study was aimed at examining the role of $5-\mathrm{HT}_{3}$ receptors in basal and depolarization-evoked dopamine release from slices of rat olfactory tubercle, a terminal field of the mesolimbic dopaminergic system. Tritium efflux was measured after loading the slices with $\left[{ }^{3} \mathrm{H}\right]$-dopamine both under basal conditions and after stimulation with $\mathrm{KCl}$. Slices from rat striatum were comparatively studied. In this region, endogenous dopamine release was also studied. A preliminary report of this study has been presented elsewhere (Del Río \& Zazpe, 1993). 


\section{Methods}

\section{Preparation of brain slices}

Olfactory tubercles or corpora striata from male Wistar rats (200-250 g) were dissected and cut sagitally into $350 \mu \mathrm{m}$ sections with a Mcllwain tissue slicer. Each superfusion chamber contained tissue from two rats. The cut tissue was washed three times in gassed $\left(95 \% \mathrm{O}_{2} / 5 \% \mathrm{CO}_{2}\right) \mathrm{Krebs}$ solution $\left(\mathrm{NaCl} 113 ; \mathrm{NaHCO}_{3} 25 ; \mathrm{KCl} 4.75 ; \mathrm{NaH}_{2} \mathrm{PO}_{4} 1.18 ; \mathrm{CaCl}_{2}\right.$ 2.52; $\mathrm{MgSO}_{4}$ 1.19; glucose 10 and pargyline $0.01 \mathrm{mM}$ ).

\section{Release of endogenous dopamine}

The slices were placed in $1 \mathrm{ml}$ chambers and superfused in an overflow manner at a rate of $0.5 \mathrm{ml} \mathrm{min}^{-1}$ with gassed Krebs solution at $37^{\circ} \mathrm{C}$. After a $75 \mathrm{~min}$ equilibration period, $1.5 \mathrm{ml}$ samples were collected into tubes containing $166 \mu \mathrm{l}$ of a solution of $1 \mathrm{~N} \mathrm{HClO}_{4}, 0.1 \%$ ascorbic acid and $20.8 \mathrm{ng}$ of dihydroxybenzylamine as an internal standard. At selected times, slices were exposed to the 5-HT agonist for $12 \mathrm{~min}$ by transferring the chamber inflow tubing to reservoirs containing medium of appropriate composition. When the interaction of a given compound with the 5-HT agonist was studied, slices were perfused with the compound $30 \mathrm{~min}$ before adding the 5-HT agonist. Dopamine (DA) release was calculated as percentage increase over basal release. The concentration of DA was determined by high-pressure liquid chromatography with electrochemical detection as previously described (PérezOtaño et al., 1991).

\section{Release of $\left[{ }^{3} \mathrm{H}\right]$-dopamine}

Slices were incubated with agitation in $5 \mathrm{ml}$ of gassed Krebs solution with $0.1 \mu \mathrm{M}\left[{ }^{3} \mathrm{H}\right]$-dopamine $\left(35 \mathrm{Ci} \mathrm{mmol}^{-1}\right.$, Amersham). After this time the tissue was washed three times with normal Krebs and the superfusion procedure was initiated as above. The equilibration period was $90 \mathrm{~min}$. Samples were collected and $80 \mu \mathrm{l}$ aliquots were added to $4 \mathrm{ml}$ of scintillation fluid (Biogreen no. 3) for radioactivity counting. Under the present experimental conditions, it is generally accepted that the radioactivity released from slices is predominantly [ $\left.{ }^{3} \mathrm{H}\right]$-DA (e.g. Werling et al., 1988).

\section{$\mathrm{K}^{+}$-evoked release of $\left[{ }^{3} \mathrm{H}\right]$-dopamine}

Slices were placed in a Krebs solution containing $39.75 \mathrm{mM}$ $\mathrm{KCl}$ (tonicity maintained by reducing the $\mathrm{NaCl}$ concentration) and the flasks were shaken at $37^{\circ} \mathrm{C}$ for $20 \mathrm{~min}$. After being washed the slices were incubated at $37^{\circ} \mathrm{C}$ for $30 \mathrm{~min}$ in normal Krebs buffer containing $0.1 \mu \mathrm{M} \quad\left[{ }^{3} \mathrm{H}\right]$-dopamine

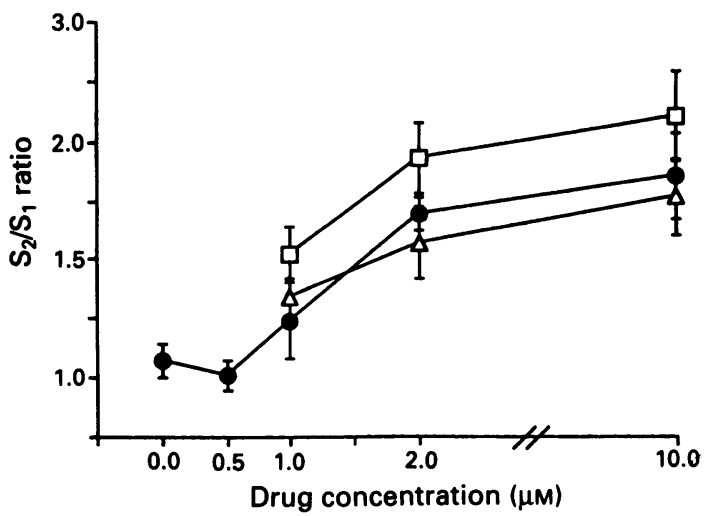

Figure 1 Concentration-dependent increase induced by 2-methyl-5HT (O), 1-phenylbiguanide $(\Delta)$ and 5 -HT $(\square)$ in $\mathrm{K}^{+}$-evoked $\left[{ }^{3} \mathrm{H}\right.$ ]dopamine efflux from rat olfactory tubercle slices preloaded with $\left[{ }^{3} \mathrm{H}\right]$-dopamine. Data are means ( \pm s.e.mean) of 4-10 experiments. $\left(35 \mathrm{Ci} \mathrm{mmol}^{-1}\right)$. Washed slices were placed into $1 \mathrm{ml}$ superfusion chambers and superfused with Krebs solution $(0.5 \mathrm{ml}$ $\min ^{-1}$ ) at $37^{\circ} \mathrm{C}$. After a $35 \mathrm{~min}$ washout period, $3 \mathrm{~min}$ samples of perfusate were collected. At $12 \mathrm{~min}\left(\mathrm{~S}_{1}\right)$ and $42 \mathrm{~min}\left(\mathrm{~S}_{2}\right)$ the slices were depolarized by changing the superfusion fluid for $6 \mathrm{~min}$ to a Krebs solution containing $20 \mathrm{mM}$ $\mathrm{KCl}$. All test drugs were added $15 \mathrm{~min}$ before $S_{2}$. The superfusate samples were collected over a $60 \mathrm{~min}$ period. $S_{2}$ and $S_{1}$ were calculated as $\mathrm{K}^{+}$-stimulated tritium increase on basal efflux.

\section{Drugs and chemicals}

The following drugs were used: $\left[{ }^{3} \mathrm{H}\right]-$ dopamine (Amersham), 5-hydroxytryptamine, creatinine sulphate, cocaine and pargyline (Sigma), 2-methyl-5-HT, 1-phenylbiguanide and nomifensine (RBI), tropisetron (Sandoz), granisetron (SmithKline Beecham) and ondansetron (Glaxo). Inorganic salts and all other reagents were from Merck.

\section{Results}

Effect of 5-HT agoniss on $\mathrm{K}^{+}$-evoked $\left[{ }^{3} \mathrm{H}\right]-\mathrm{DA}$ release from olfactory tubercle slices

Tritium efflux was practically the same after the two $\mathrm{K}^{+}$ pulses $\left(\mathrm{S}_{2} / \mathrm{S}_{1}\right.$ ratio $\left.=1.07 \pm 0.07 ; n=7\right)$. The selective $5-\mathrm{HT}_{3}$ receptor agonist 2-methyl-5-HT (2-Me-5-HT) produced a concentration-dependent increase in $\mathrm{K}^{+}$-evoked $\left[{ }^{3} \mathrm{H}\right]-\mathrm{DA}$ efflux $\left(S_{2} / S_{1}\right.$ ratio) from slices of rat olfactory tubercle preloaded with $\left[{ }^{3} \mathrm{H}\right]-\mathrm{DA}$ (Figure 1). Phenylbiguanide (PBG) produced substantially the same effect and 5-HT was not significantly more potent than the selective $5-\mathrm{HT}_{3}$ agonists (Figure 1). The $\mathrm{K}^{+}$-evoked $\left[{ }^{3} \mathrm{H}\right]$-DA efflux was virtually absent in the absence of $\mathrm{Ca}^{2+}$ in the superfusion medium (not shown). Tetrodotoxin (TTX, $1 \mu \mathrm{M}$ ) partially blocked the $\mathrm{K}^{+}$-evoked tritium overflow. $\mathrm{S}_{2} / \mathrm{S}_{1}$ for control and TTX was $1.07 \pm 0.07$ and $0.83 \pm 0.07$ respectively $(n=5 ; P<0.05)$. A similar percentage blockade was observed in slices stimulated with $\mathrm{K}^{+}$and 2-Me-5-HT (2-Me-5-HT, $1.69 \pm 0.07$; TTX + 2Me-5-HT, $1.35 \pm 0.09$ ).

\section{Effect of 5-HT agonists on basal DA release from olfactory tubercle or striatal slices}

The percentage release from striatal slices produced by 5 -HT on either tritiated or endogenous DA was practically identical. The percentage release of $\left[{ }^{3} \mathrm{H}\right]-\mathrm{DA}$ obtained from olfactory tubercle slices was slightly higher (Figure 2). Selective $5-\mathrm{HT}_{3}$ receptor agonists produced a weaker effect on DA

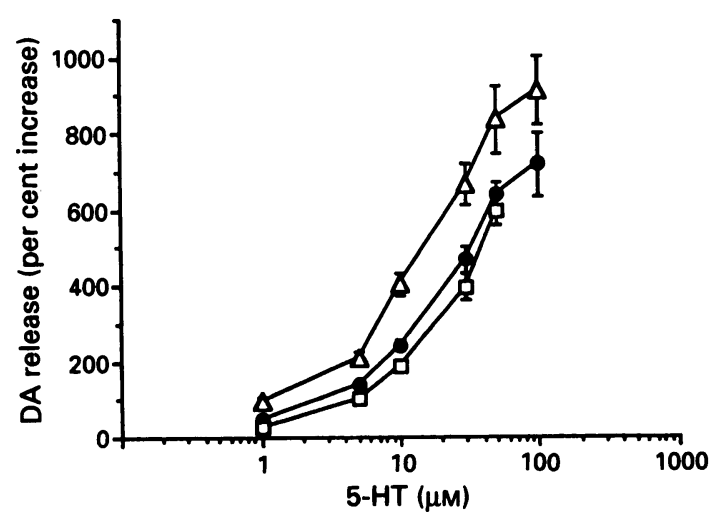

Figure 2 Effect of 5-HT on dopamine release from rat brain slices (per cent increase over basal values). Data are means ( \pm s.e.mean) of at least five separate experiments $(\Delta-. \Delta)\left[{ }^{3} \mathrm{H}\right]$-dopamine, olfactory tubercle; (O... ) $\left[{ }^{3} \mathrm{H}\right]$-dopamine, striatum ( $\square$-... $\square$ ) endogenous dopamine, striatum. 
Table 1 Effect of 5-HT and 5- $\mathrm{HT}_{3}$ receptor agonists on release of tritiated or endogenous dopamine from rat striatal (str.) and olfactory tubercle (o.t.) slices

$\begin{array}{lccc}\text { 5-HT agonist }(\mu M) & {\left[{ }^{3} H\right]-D A(o . t .)} & D A \text { (str.) } \\ \text { 5-HT (10) } & 405 \pm 28 & 242 \pm 12 & 188 \pm 10 \\ \text { PBG (10) } & 241 \pm 23 & 166 \pm 14 & 118 \pm 18 \\ \text { PBG (30) } & 438 \pm 32 & 256 \pm 20 & 238 \pm 52 \\ \text { 2-Me-5-HT (100) } & 122 \pm 18 & 53 \pm 7 & \text { n.d. }\end{array}$

Data (means \pm s.e.; $n=4-6$ ) are expressed as per cent increase over basal release. PBG, 1 phenylbiguanide; n.d., not determined.

release (Table 1). The releasing effect of 2-Me-5-HT on endogenous dopamine was not determined because of interference of the chromatographic peak of this drug with dopamine. In all cases, the release was not modified by omission of $\mathrm{Ca}^{2+}$ in the superfusion medium and was tetrodotoxin insensitive (not shown).

Basal $\left[{ }^{3} \mathrm{H}\right]-\mathrm{DA}$ release was also studied in olfactory tubercle slices pre-exposed for $20 \mathrm{~min}$ to a high- $\mathrm{K}^{+}$solution, as in the above experiments on $\mathrm{K}^{+}$-evoked $\left[{ }^{3} \mathrm{H}\right]-\mathrm{DA}$ efflux, and no difference in percentage release was apparent after this previous exposure. Using these experimental conditions, the percentage increase in basal $\left.{ }^{3} \mathrm{H}\right]-\mathrm{DA}$ release induced by $5 \mu \mathrm{M}$ 5-HT was $188.7 \pm 19.3$ (mean \pm s.e.mean of five experiments), and 2-Me-5-HT $(10-50 \mu \mathrm{M})$ did not show any significant effect on basal $\left[{ }^{3} \mathrm{H}\right]-\mathrm{DA}$ release. Endogenous DA release was not studied in striatal slices pre-exposed to a high level of $\mathrm{K}^{+}$since the rise in DA induced by $5-\mathrm{HT}$ in the subsequent experiments was not high enough for accurate chromatographic quantification.

\section{Effect of $5-\mathrm{HT}_{3}$ receptor antagonists on $\mathrm{K}^{+}$-evoked} $\left.{ }^{3} \mathrm{H}\right]-D A$ release from olfactory tubercle slices

All of the studied $5-\mathrm{HT}_{3}$ receptor antagonists lacked any intrinsic effect on $\mathrm{K}^{+}$-stimulated release. For example, $\mathbf{S}_{2} / \mathbf{S}_{1}$ ratio after $2 \mu \mathrm{M}$ ondansetron was $1.12 \pm 0.10(n=4)$. Ondansetron $(0.05-2 \mu \mathrm{M})$ produced a concentration-dependent blockade of the increased $\mathrm{K}^{+}$-evoked $\left.{ }^{3} \mathrm{H}\right]-\mathrm{DA}$ efflux induced by $2-\mathrm{Me}-5-\mathrm{HT}$ in rat olfactory tubercle slices (Figure 3 ). Other $5-\mathrm{HT}_{3}$ receptor antagonists such as granisetron and tropisetron $(0.2 \mu \mathrm{M})$ also blocked the effect of 2-Me-5-HT (Figure 3). A ten fold higher concentration $(2 \mu \mathrm{M})$ of ketanserin, a 5- $\mathrm{HT}_{2}$ receptor antagonist, did not modify the effect of 2-Me-5-HT (Figure 4). The increased $\mathrm{K}^{+}$-evoked $\left[{ }^{3} \mathrm{H}\right]-\mathrm{DA}$ efflux induced by 5 -HT was again blocked by ondansetron and not by ketanserin, $2 \mu \mathrm{M}$ each. $S_{2} / S_{1}$ ratio was $1.96 \pm 0.15,1.31 \pm 0.14$ and $1.72 \pm 0.24$ for $5-\mathrm{HT}$, 5$\mathrm{HT}+$ ondansetron and 5-HT + ketanserin respectively $(n=$ 4-6).

\section{Effect of 5- $\mathrm{HT}_{3}$ receptor antagonists on basal DA release}

At variance with the above results, much higher concentrations $(10$ or $50 \mu \mathrm{M})$ of the $5-\mathrm{HT}_{3}$ receptor antagonists ondansetron, granisetron or tropisetron did not block the increase in basal $\left[{ }^{3} \mathrm{H}\right]-\mathrm{DA}$ release from olfactory tubercle or striatal slices induced by $5-10 \mu \mathrm{M} 5-\mathrm{HT}$ or the release of endogenous DA induced by $10 \mu \mathrm{M} 5-\mathrm{HT}$ in striatal slices. Control release (per cent increase over basal) was essentially the same in all cases: $\left[{ }^{3} \mathrm{H}\right]-D A$ (olfactory tubercle), $213 \pm 21$; endogenous DA (striatum), $182 \pm 23 ;\left[{ }^{3} \mathrm{H}\right]-\mathrm{DA}$ (striatum), $229 \pm 25$. The results obtained in the presence of $5-\mathrm{HT}_{3}$ receptor antagonists were practically identical (not shown). The increase in $\left[{ }^{3} \mathrm{H}\right]-\mathrm{DA}$ induced by the $5-\mathrm{HT}_{3}$ receptor agonist PBG was not blocked by either ondansetron or tropisetron, $50 \mu \mathrm{M}$ each (not shown).

In olfactory tubercle slices pre-exposed to a high level of $\mathrm{K}^{+}, 5-\mathrm{HT}_{3}$ receptor antagonists did not block the increase in basal $\left[{ }^{3} \mathrm{H}\right]-\mathrm{DA}$ release induced by $5-\mathrm{HT}$. For example, $2 \mu \mathrm{M}$

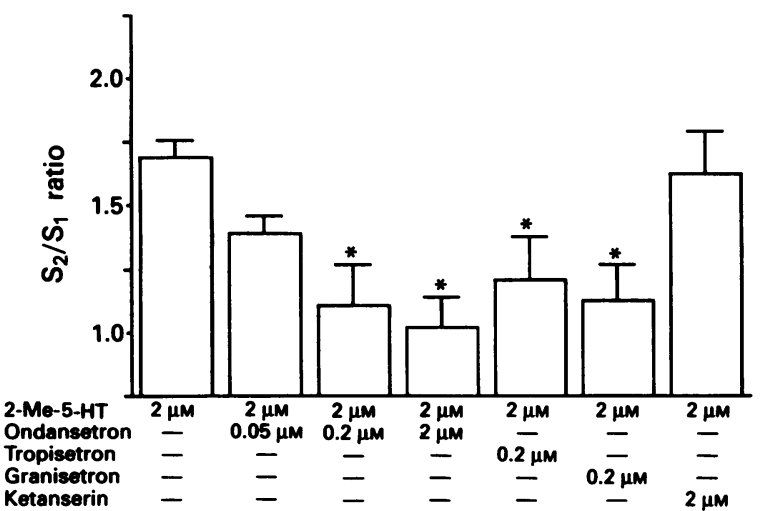

Figure 3 Effect of $5-\mathrm{HT}_{3}$ and $5-\mathrm{HT}_{2}$ receptor antagonists on the enhanced $\mathrm{K}^{+}$-evoked $\left[{ }^{3} \mathrm{H}\right]$-dopamine efflux from rat olfactory tubercle slices induced by 2-methyl-5-HT. Data are means ( \pm s.e.mean) of at least five separate experiments. ${ }^{*} P<0.01$ vs $2-\mathrm{Me}-5$-HT (Student's $t$ test).

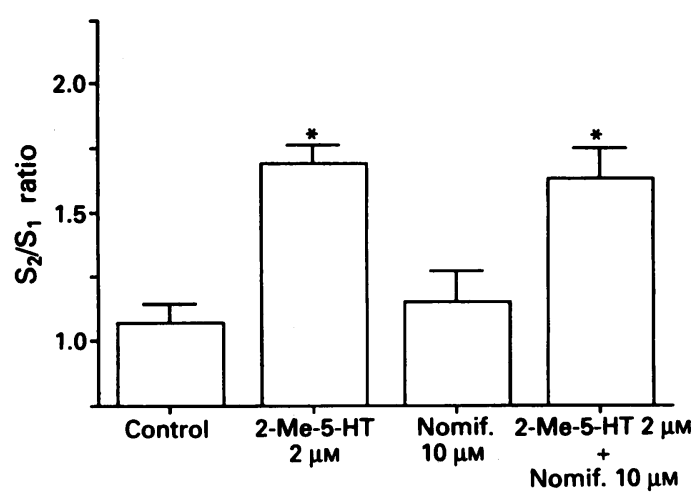

Figure 4 Lack of effect of nomifensine (nomif.) on the enhanced $\mathrm{K}^{+}$-evoked $\left[{ }^{3} \mathrm{H}\right]$-dopamine efflux from rat olfactory tubercle slices induced by 2-methyl-5-HT. Data are means ( \pm s.e.mean) of five separate experiments. ${ }^{*} P<0.01$ vs control (Student's $t$ test).

5-HT produced a percentage increase over basal values of $77.3 \pm 11.7$ and $70.3 \pm 9.4(n=5)$ when tested alone and in the presence of $2 \mu \mathrm{M}$ ondansetron respectively. A higher ondansetron concentration $(10 \mu \mathrm{M})$ was also unable to block the enhanced release after $10 \mu \mathrm{M}$ 5-HT; percentage increases were $378 \pm 29$ and $358 \pm 22$ for 5-HT and 5-HT + ondansetron respectively.

\section{Effect of DA uptake blockers on $\mathrm{K}^{+}$-evoked and basal $D A$ release from olfactory tubercle and striatal slices}

Nomifensine $(10 \mu \mathrm{M})$ did not show an intrinsic effect on $\mathrm{K}^{+}$-evoked $\left.{ }^{3} \mathrm{H}\right]$-DA efflux from rat olfactory tubercle slices. The same concentration of nomifensine did not modify the enhancing effect of $2-\mathrm{Me}-5-\mathrm{HT}$ on $\mathrm{K}^{+}$-evoked tritium efflux (Figure 4). 

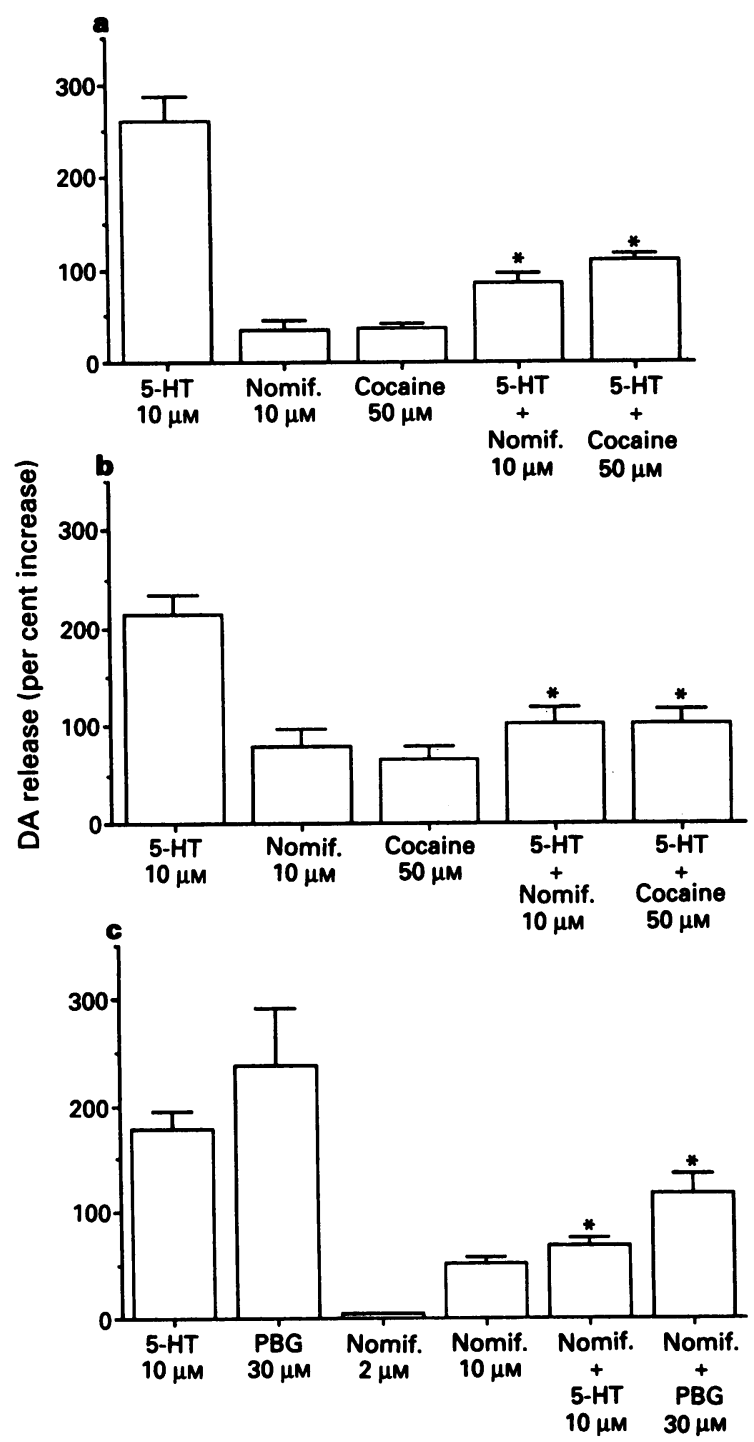

Figure 5 Blockade by nomifensine (nomif.) and cocaine of dopamine release from rat brain slices (per cent increase over basal values) induced by 5-HT or 1-phenylbiguanide (PBG). Data are means ( \pm s.e.mean); $n=4-7$. (a) $\left[{ }^{3} \mathrm{H}\right]$-dopamine, striatum; (b) $\left[{ }^{3} \mathrm{H}\right]$ dopamine, olfactory tubercle; (c) endogenous dopamine, striatum. ${ }^{*} P<0.01$ vs 5-HT (Student's $t$ test).

Basal $\left[{ }^{3} \mathrm{H}\right]-\mathrm{DA}$ release was not modified by $2 \mu \mathrm{M}$ nomifensine or $10 \mu \mathrm{M}$ cocaine and was enhanced by five fold higher concentrations of the DA uptake blockers (Figure $5 a$ and $b$ ). Both nomifensine $(10 \mu \mathrm{M})$ and cocaine $(50 \mu \mathrm{M})$ were able to significantly block the much larger increase in basal $\left[{ }^{3} \mathrm{H}\right]-\mathrm{DA}$ release from striatal or olfactory tubercle slices induced by 5-HT (Figure 5a and b). The lower concentrations of nomifensine and cocaine, 2 and $10 \mu \mathrm{M}$ respectively, also produced a small but significant decrease in 5 -HT-induced $\left[{ }^{3} \mathrm{H}\right]-\mathrm{DA}$ release (not shown). Nomifensine also blocked the increase in endogenous DA release from striatal slices produced by 5HT or PBG (Figure 5c).

\section{Discussion}

The present results provide evidence for the modulation by $5-\mathrm{HT}_{3}$ receptors of $\mathrm{K}^{+}$-evoked dopamine release from slices of rat olfactory tubercle. Conversely, when terminal fields of the mesolimbic or nigrostriatal dopaminergic system are not activated with $\mathrm{K}^{+}, 5-\mathrm{HT}$ and $5-\mathrm{HT}_{3}$ receptor stimulants enhance dopamine release through a carrier-mediated mechanism.
Previous studies have addressed the role of $5-\mathrm{HT}_{3}$ receptors in dopamine release by using either slices (Blandina $e t$ al., 1989; Benuck \& Reith, 1992; Jacocks \& Cox, 1992) or synaptosome preparations (Yi et al., 1991) from rat brain regions and measuring either endogenous dopamine release or tritium efflux after preloading the preparation with $\left[{ }^{3} \mathrm{H}\right]-$ DA. In the present study, all experiments were carried out in brain slices, which allow the detection of effects mediated by receptors located not only on nerve terminals but also on interneurones. As to the interest in measuring tritium efflux or endogenous dopamine release, previous studies indicate that tritium efflux closely mimics endogenous dopamine release (Herdon et al., 1985; Werling et al., 1988). The almost identical results obtained with striatal slices in the present study (Figure 3) corroborate this assumption.

In keeping with several previous studies (Nurse et al., 1988; Schmidt \& Black, 1989; Yi et al., 1991; Benuck \& Reith, 1992; Jacocks \& Cox, 1992), 5-HT-enhanced $\left[{ }^{3} \mathrm{H}\right]-\mathrm{DA}$ release was prevented by DA uptake blockers and not by $5-\mathrm{HT}_{3}$ receptor antagonists. Partial depletion of endogenous DA stores by pre-exposure of the slices to a high level of $\mathrm{K}^{+}$did not modify the effect of $5-\mathrm{HT}$ or $2-\mathrm{Me}-5-\mathrm{HT}$ on basal $\left[{ }^{3} \mathrm{H}\right]-$ DA release and, likewise, $5-\mathrm{HT}_{3}$ receptor antagonists were unable to block the enhancement in basal $\left[{ }^{3} \mathrm{H}\right]-\mathrm{DA}$ efflux induced by 5-HT. This is consonant with the ability of PBG to promote $\left[{ }^{3} \mathrm{H}\right]-\mathrm{DA}$ efflux in striatal slices from rats pretreated with reserpine (Benuck \& Reith, 1992): not only are endogenous DA stores markedly reduced but DA storage mechanisms are also affected. Release of either endogenous or tritiated dopamine by $5-\mathrm{HT}$ or $5-\mathrm{HT}_{3}$ receptor agonists was not dependent on $\mathrm{Ca}^{2+}$ and was also tetrodotoxin insensitive, thus supporting the notion of a carrier-mediated release of the neurotransmitter (see Levi \& Raiteri, 1993). However, our results are not in accordance with those reported by Blandina et al. (1989), who found that $5-\mathrm{HT}_{3}$ receptor antagonists are able to prevent endogenous DA release from striatal slices. Since in their study all experiments were carried out in the presence of nomifensine, it is possible that other mechanisms may still be operative in such an experimental condition. The comparatively low density of 5- $\mathrm{HT}_{3}$ receptors in the striatum compared with limbic and cortical areas (Kilpatrick et al., 1988) raises some doubt about their physiological significance in this brain region.

$\mathrm{K}^{+}$-stimulated dopamine release from the olfactory tubercle showed a strong $\mathrm{Ca}^{2+}$ dependence, consistent with an exocytotic mechanism. At a $20 \mathrm{mM} \mathrm{K} \mathrm{K}^{+}$concentration, the neuronal firing would be activated and this would activate in turn $\mathrm{Ca}^{2+}$ influx (Illes, 1986). However, $\mathrm{K}^{+}$-evoked dopamine release was only partially tetrodotoxin sensitive, indicating that only a part of the $\mathrm{K}^{+}$-stimulated release is dependent on excitatory input from sites distal to the terminal (Jacocks \& Cox, 1992). Tetrodotoxin blocked to approximately the same extent the enhancement by $2-\mathrm{Me}-5-\mathrm{HT}$ of the $\mathrm{K}^{+}$stimulated release, suggesting that $5-\mathrm{HT}_{3}$ receptor activation potentiates the $\mathrm{K}^{+}$effect, probably by contributing to a greater ionic influx through opening of the associated 5-HTgated channel (Derkach et al., 1989).

Forebrain $5-\mathrm{HT}_{3}$ receptors are concentrated in terminal fields of the mesolimbic dopaminergic system, such as the olfactory tubercle (Kilpatrick et al., 1988) so their role at this level should be more relevant than at the striatum. Interestingly, it seems that these receptors are only operative in the control of dopamine release when dopaminergic terminals have been depolarized by a high potassium concentration. Under these experimental conditions, there is not a marked difference in potency between the specific $5-\mathrm{HT}_{3}$ receptor agonists 2-Me-5-HT or PBG and 5-HT, as is the case when their effects on basal dopamine release are compared. It is possible that under conditions of $\mathrm{K}^{+}$-stimulated exocytotic release 5-HT may act also on presynaptic receptors inhibiting dopamine release (see Levi \& Raiteri, 1993). The enhancement of $\mathrm{K}^{+}$-evoked dopamine release by 5 -HT seems to be dependent on $5-\mathrm{HT}_{3}$ receptor stimulation and not on activa- 
tion of any other 5-HT receptor subtype. The lack of blockade by ketanserin of the 5-HT effect argues against the involvement of 5- $\mathrm{HT}_{2}$ receptors, which rather appear to control carrier-mediated release of dopamine (Nash, 1990; Huang \& Nichols, 1993).

The results of the present study showing that $5-\mathrm{HT}_{3}$ receptor antagonists are only able to prevent the effect of serotonergic stimulation on terminal fields of the mesolimbic dopaminergic system when this system has been previously

\section{References}

BARNES, J.M., BARNES, N.M., CHAMPANERIA, S., COSTALL, B. \& NAYLOR, R.J. (1990). Characterization and autoradiographic localization of $5-\mathrm{HT}_{3}$ receptor recognition sites identified with $\left[{ }^{3} \mathrm{H}\right]-(\mathrm{S})$-zacopride. Neuropharmacology, 29, 1037-1045.

BENUCK, M. \& REITH, M.E.A. (1992). Dopamine releasing effect of phenylbiguanide in rat striatal slices. Naunyn-Schmied. Arch. Pharmacol., 345, 666-672.

BLANDINA, P., GOLDFARB, J., CRADDOCK-ROYAL, B. \& GREEN, J.P. (1989). Release of endogenous dopamine by stimulation of 5-hydroxytryptamine ${ }_{3}$ receptors in rat striatum. J. Pharmacol. Exp. Ther., 251, 803-809.

CARBONI, E., ACQUAS, E., FRAU, R. \& DI CHIARA, G. (1989) Differential inhibitory effects of a $5-\mathrm{HT}_{3}$ antagonist on druginduced stimulation of dopamine release. Eur. J. Pharmacol., 164, 515-519.

COSTALL, B., DOMENEY, A.M., NAYLOR, R.J. \& TYERS, M.B. (1987) Effects of the 5-HT ${ }_{3}$ receptor antagonist, GR $38032 \mathrm{~F}$, on raised dopaminergic activity in the mesolimbic system of rat and marmoset brain. Br. J. Pharmacol., 92, 881-894.

CHEN, J., VAN PRAAG, H.M. \& GARDNER, E.L. (1991). Activation of $5-\mathrm{HT}_{3}$ receptor by 1 -phenylbiguanide increases dopamine release in the rat nucleus accumbens. Brain Res., 543, 354-357.

DEL RIO, J. \& ZAZPE, A. (1993). Release of dopamine from rat olfactory tubercle is mediated by activation of $5-\mathrm{HT}_{3}$ receptors. Soc. Neurosci. Abstr., 23, 1380.

DERKACH, V., SUPRENANT, A. \& NORTH, R.A. (1989). 5-HT3 receptors are membrane ion-channels. Nature, 339, 706-709.

HAGAN, R.M., BUTLER, A., HILL, J.M., JORDAN, C.C., IRELAND, S.J. \& TYERS, M.B. (1987). Effect of the 5- $\mathrm{HT}_{3}$ receptor antagonist, GR $38032 \mathrm{~F}$, on responses to injection of a neurokinin agonis into the ventral tegmental area of the brain. Eur. J. Pharmacol., 138, 303-305.

HAGAN, R.M., KILPATRICK, G.J. \& TYERS, M.B. (1993). Interactions between $5-\mathrm{HT}_{3}$ receptors and cerebral dopamine function: implications for the treatment of schizophrenia and psychoactive substance abuse. Psychopharmacology, 112, S68-S75.

HERDON, H., STRUPISH, J. \& NAHORSKI, S.R. (1985). Differences between the release of radiolabelled and endogenous dopamine from superfused rat brain slices: effect of depolarizing stimuli, amphetamine and synthesis inhibition. Brain Res., 348, 309-320.

HUANG, X. \& NICHOLS, D.E. (1993). 5-HT 2 receptor-mediated potentiation of dopamine synthesis and central serotonergic deficits. Eur. J. Pharmacol., 238, 291-296.

ILLES, P. (1986). Mechanisms of receptor-mediated modulation of transmitter release in noradrenergic, cholinergic and sensory neurons. Neuroscience, 17, 909-928.

IMPERATO, A., PUGLISI-ALLERGRA, S., ZOCCHI, A., SCROCCO, M.G., CASOLINI, P. \& ANGELUCCI, L. (1990). Stress activation of limbic and cortical dopamine release is prevented by ICS205-930 but not diazepam. Eur. J. Pharmacol., 175, 211-214.

JACOCKS, H.M. \& COX, B.M. (1992). Serotonin-stimulated release of $\left[{ }^{3} \mathrm{H}\right]$ dopamine via reversal of the dopamine transporter in rat striatum and nucleus accumbens: a comparison with release elicited by potassium, N-methyl-D-aspartic acid, glutamic acid and D-amphetamine. J. Pharmacol. Exp. Ther., 262, 356-364. activated by $\mathrm{K}^{+}$offer parallelism with many in vivo studies and stress the potential psychiatric interest of a class of drugs that would only be affecting the dopaminergic system under conditions of abnormal activation.

We thank Gobierno de Navarra (Spain) for a fellowship to one of us (I.A.). The generous gift of drugs by pharmaceutical companies is gratefully acknowledged.

JIANG, L.H., ASHBY, Jr. C.R., KASSER, R.J \& WANG, R.Y. (1990). The effect of intraventricular administration of the $5-\mathrm{HT}_{3}$ receptor agonist 2-methyl-serotonin on the release of dopamine in the nucleus accumbens: an in vivo chronocoulometric study. Brain Res., 513, 156-160.

KILPATRICK, G.J., JONES, B.J. \& TYERS, M.B. (1988). The distribution of specific binding of the $5-\mathrm{HT}_{3}$ receptor ligand $\left[{ }^{3} \mathrm{H}\right]$ GR 65630 in rat brain using quantitative autoradiography. Neurosci. Lett., 94, 156-160.

KOOB, G.F. \& BLOOM, F.E. (1988). Cellular and molecular mechanisms of drug dependence. Science, 242, 715-722.

LEVI, G. \& RAITERI, M. (1993). Carrier-mediated release of neurotransmitters. Trends Neurosci., 16, 415-419.

NASH, J.F. (1990). Ketanserin pretreatment attenuates MDMAinduced dopamine release in the striatum as measured by in vivo microdialysis. Life Sci., 47, 2401-2408.

NURSE, B., RUSSELL, V.A. \& TALJAARD, J.J.F. (1988). Characterization of the effects of serotonin on the release of $\left[{ }^{3} \mathrm{H}\right]$ dopamine from rat nucleus accumbens and striatal slices. Neurochem. Res., 13, 403-407.

PALFREYMAN, M.G., SCHMIDT, C.J., SORENSEN, S.M., DUDLEY, M.W., KEHNE, J.H., MOSER, P., GITTOS, M.W. \& CARR, A.A. (1993). Electrophysiological, biochemical and behavioural evidence for 5-HT2 and 5-HT3 mediated control of dopaminergic function. Psychopharmacology, 112, S60-S67.

PEREZ-OTAÑo, I., HERRERO, M.T., OSET, C., DE CEBALlOS, M.L., LUQUIN, M.R., OBESO, J.A. \& DEL RIO, J. (1991). Extensive loss of brain dopamine and serotonin induced by chronic administration of MPTP in the marmoset. Brain Res., 567, 127-132.

SCHMIDT, C.J. \& BLACK, C.K. (1989). The putative 5-HT 3 agonist phenylbiguanide induces carrier-mediated release of $\left[{ }^{3} \mathrm{H}\right] \mathrm{dopa}-$ mine. Eur. J. Pharmacol., 167, 309-310.

SORENSEN, S., HUMPHREYS, T.M. \& PALFREYMAN, M.G. (1989). Effect of acute and chronic MDL 73,147EF, a 5-HT receptor antagonist, on A9 and A10 dopamine neurones. Eur. J. Pharmacol., 163, 115-118.

WAEBER, C., HOYER, D. \& PALACIOS, J.M. (1989). 5-Hydroxytryptamine receptors in the human brain, autoradiographic visualization using [ $\left.{ }^{3} \mathrm{H}\right] \mathrm{ICS}$ 205-930. Neuroscience, 31, 393-400.

WERLING, L.L., FRATTALI, P., PORTOGHESE, P.S., TAKEMORI, A.E. \& COX, B.M. (1988). Kappa receptor regulation of dopamine release from striatum and cortex of rats and guinea-pigs. $J$. Pharmacol. Exp. Ther., 246, 282-286.

YI, S.-J., GIFFORD, A.N. \& JOHNSON, K.M. (1991). Effect of cocaine and $5-\mathrm{HT}_{3}$ receptor antagonists on 5 -HT-induced $\left[{ }^{3} \mathrm{H}\right]$ dopamine release from rat striatal synaptosomes. Eur. J. Pharmacol., 199, $185-189$.

(Received March 3, 1994

Revised July 28, 1994

Accepted August 2, 1994) 